UDC 811.163.4'28

UDC 811.163.41'366.545

https://doi.org/10.18485/ms_zmsfil.2021.64.1.5

Изворни научни рад

Светлана Ћирковић

\title{
НЕЗАМЕНИЧКА УПОТРЕБА ЕНКЛИТИЧКОГ ОБЛИКА ДАТИВА РЕФЛЕКСИВНЕ ЗАМЕНИЦЕ СИ У ТИМОЧКИМ ГОВОРИМА: СИНТАКСИЧКИ ОБРАСЦИ*
}

\begin{abstract}
Рад се бави незаменичком употребом енклитичког облика датива рефлексивне заменице себе/се, језичком одликом типичном за говоре призренско-тимочке дијалекатске зоне, којој припадају и тимочки говори, који су у фокусу анализе у овом раду. Под незаменичком функцијом се у овом раду сматрају они случајеви употребе енклитичког облика датива рефлексивне заменице који у функционалном смислу не припадају заменичким функцијама (као што су индиректни објекат и адноминални посесор). Циљ овог рада је да се на основу теренски документоване грађе тимочких говора издвоје најфреквентнији обрасци употребе партикуле $c u$, који би могли да укажу на потенцијалне синтаксичке правилности, али и варијације синтаксичких образаца њене употребе.

Кључне речи: енклитички облик рефлексивне заменица себе/се, партикула $\mathrm{cu}$, синтаксички обрасци, тимочки говори.

This paper discusses the non-pronominal use of the enclitic form of the dative case of the reflexive pronoun sebe/se, a linguistic feature typical of vernaculars from the Prizren-Timok dialectal area, which includes the Timok vernaculars in the focus of this analysis. For the purposes of this paper the non-pronominal function includes cases of the enclitic form of the dative case of the reflexive pronoun, which in a functional sense do not represent pronominal functions (such as indirect object and adnominal possessor). The objective of this paper is to identify the most frequent patterns of use of the particle $s i$-based on documented material collected in the field - which could indicate potential syntactic regularities, as well as variations of syntactic patterns of its use.

Key words: dative enclitic of the reflexive pronoun sebe/se, particle si, syntactic patterns, Timok vernaculars.
\end{abstract}

1. Увод. Партикула $c u$ у морфолошком смислу представља енклитички облик датива рефлексивне заменице себе/се, а осим незаменичке употребе (илустроване примером: Ми си овgе сеgимо), у говорима призренско-тимочке дијалекатске зоне користи се и у заменичком значењу - као индиректни објекат (као у примеру: Понели смо си јеgење) и адноминални посесор (као у примеру: Саg си жалим брайанче) (уп. нпр. Соболев 2012; Vuкоvić et al. 2021). Ни заменичка ни незаменичка употреба дативне енклитике $c u$ не сматра

* Ова студија је резултат рада у Балканолошком институту САНУ, који финансира Министарство просвете, науке и технолошког развоја РС, а на основу уговора о реализацији и финансирању научноистраживачког рада НИО у 2021. години, број 451-03-9/2021-14/200170 од 05.02.2021 и међународног пројекта (Dis-)entangling Traditions on the Central Balkans: Performance and Perception ( $\mathrm{TraCeBa),} \mathrm{који} \mathrm{се} \mathrm{спроводи} \mathrm{у} \mathrm{оквиру} \mathrm{програма} \mathrm{Era.netRUS.plus} \mathrm{(пот-}$ програм FP7/Horizon 2020), у сарадњи Славистичког семинара Универзитета у Цириху (Швајцарска), Института за лингвистику Руске академије наука (Санкт Петербург, Русија), Филолошког факултета Универзитета у Београду и истраживача из Балканолошког института САНУ (Београд, Србија). Пројектни тим из Србије финансира Министарство просвете, науке и технолошког развоја Републике Србије. 
се одликом стандардног српског језика. ${ }^{1}$ Незаменичка употреба датива енклитике $c u$ предмет је бројних лингвистичких студија (не само дијалектолошких), будући да ову језичку црту испољавају не само говори призренско-тимочке дијалекатске области српског језика и балканских словенских језика и дијалеката, већ и несловенских и неиндоевропских језика и језичких варијетета (о чему ће бити речи у прегледу литературе). У зависности од теоријског и методолошког приступа овом језичком феномену, о значењу клитике $c u$ говори се најчешће као о евалуативном, прагматичком и модалном (ARSENIJEVIć 2013; Petrova - Sokolov 2016; Савова 2017; Иванова - Петрова 2017; МиЛосАвљевић 2019, између осталих). ${ }^{2}$

2. ПАРТИКУЛА СИ У ДИЈАЛЕКТОЛОШКИМ, СИНТАКСИЧКИМ И СЕМАНТИЧКИМ студијАмА. Употреба датива личних заменица и/или рефлексивне заменице за означавање ситуације која има позитивно дејство на субјекта, задовољавајући његове циљеве, одвијајући се у његову корист (МилосАвљЕвић 2019: 48) језички је феномен који, уз одређене варијације, постоји у словенским (бугарски, македонски, чешки, пољски, хрватски) и несловенским језицима индоевропске породице језика (амерички енглески, француски, шпански, холандски). ${ }^{3}$ Осим у индоевропским језицима испољава се и у семитским језицима: стари и модерни хебрејски, сиријски арапски, либански арапски (ArsenijeVić 2013; МилосАвљевй 2019). У српском језику не сматра се стандарднојезичком цртом, већ типично дијалекатском.

У српској дијалектолошкој литератури, која покрива говоре призренско-тимочке дијалекатске зоне (чији су део и тимочки говори), морфолошка форма $c$ се разматра у оквиру парадигме личних заменица описиваног говора. Различите функције овог морфолошког облика - синтаксичка, семантичка, прагматичка и/или модална, у дијалектолошким студијама нису посебно разматране. О значењу енклитике си у српској дијалектологији се говори као о „дативском значењу” (ПАвловић 1970; БогдАновић 1979; Ћирић 1983; 1999) и ,заменичком значењу” (БогдАновић 1987; ВукАдиновић 1996). Дијалектолози примећују да енклитички облик датива рефлексивне заменице себе/се губи своје заменичко и дативско значење и да се користи као „речца” (Ћирић 1999; Јуришић 2009), „речца за појачавање” (Реметић 1996; МАрковић 2000), „речца која губи заменичко значење, али не сасвим и могућност локализовања садржаја предиката на ужу сферу субјекта" (БогдАновић 1987). У неким студијама се говори о „плеонастичкој употреби си” (СтАнолевић 1911; Ћирит 1983), ,еуфемистичкој употреби говорног лица” (Ћирић 1983), или као о ,устаљеном изразу” (ВукАдиновић 1996). Употреба енклитике си у „незаменичком значењу” елицитира се и синтаксичким упитником за говоре косовско-ресавске и призренско-тимочке дијалекатске зоне (РАкић-Милолковић 1995: 527).

\footnotetext{
${ }^{1}$ Нормативна граматика српског језика ни у једном сегменту се не дотиче дативне енклитике $c u$ у наведним функцијама (уп. ПипеР - КлАлн 2013).

2 У лингвистичкој литератури се користи и термин „,middle voice marker”, који истиче својство дативне енклитике $c u$ да се радња исказана глаголом уз који стоји $с и$ врши у корист субјекта, као и да је опозиција између агенса и пацијенса неутрализована (KEMMER 1993).

${ }^{3}$ Набројаним језицима треба додати и ромски језик (UhLIK 1973: 75-83; MATRAs 2002: 101; LEGGIO 2011: 75)
} 
Значајно је напоменути да у дијалектолошкој литератури у којој се описују говори косовско-ресавске говорне зоне није регистрована незаменичка употреба енклитичког облика датива рефлексивне заменице себе/се (уп. нпр. Пецо - МилАновић 1968; РАкић-Милолковић 1990; РАдић 2010). Осим тога, примећује се да поједини косовско-метохијским говори који припадају призренско-тимочкој дијалекатској зони такође у свом систему не садрже ову језичку црту (уП. нпр. МлАДЕновић 2001: 340; 2010: 42, 44; 2013: 231). ${ }^{4}$

У синтаксичко-семантичким студијама Бобана Арсенијевића (ARSENIJEVIĆ 2013) и Стефана Милосављевића (МилосАвљевић 2019), насталих на материјалу говора који припадају призренско-тимочкој дијалекатској зони (говор Ниша (ARSENIJEVIĆ 2013), говор јабланичког краја (МилосАвљевић 2019)), енклитички облик датива рефлексивне заменице у незаменичкој функцији означен је термином „евалуативни рефлексивни датив” (енг. evaluative dative reflexive). Функција евалуативног рефлексивног датива је евалуација ситуације исказане глаголом у предикату (ARSENIJEVIĆ 2013). Према Бобану Арсенијевићу, својства евалуативног рефлексивног датива (ЕРД) су: 1) ЕРД је увек реализован рефлексивном заменицом, 2) субјекат са којим је повезан ЕРД показује интенционалност, 3) субјекат позитивно вреднује ситуацију у клаузи, 4) ЕРД се не комбинује са фокалним елементима са евалуативном интерпретацијом, 5) ЕРД имплицира да је информација пренета клаузом мање релевантна, 6) субјекат са којим је повезан ЕРД мора да буде тема, 7) субјекат клаузе која садржи ЕРД мора бити референцијалан, 8) ЕРД се не комбинује са више субјеката (ARSENIJEVIĆ 2013: 5).

Стефан Милосављевић (2019) пореди својства евалуативног рефлексивног датива у говору јабланичког краја са својствима која је истакао Арсенијевић. Према Милосављевићу, својство ЕРД-а да субјекат клаузе која садржи ЕРД мора да укључује интенционалност изостаје у оним случајевима када је субјекат неаниматан (интенционалност се у том случају постиже персонификацијом) или када субјекат реферише на пропозицију или скуп пропозиција - у тим случајевима се не може говорити о интенционалности субјекта. Милосављевић у говору јабланичког краја бележи и примере са ЕРД у којима је субјекат нереференцијалан, не мора нужно да буде тема (и ту истиче примере са безличним клаузама), а ситуација коју евалуира субјекат не мора да буде позитивна, већ се ЕРД може комбиновати са било којом ситуацијом, па и негативном (МилосАвљЕвић 2019: 48-50). На тај начин, кључно својство ЕРД (његов семантички потенцијал), према Милосављевићу, јесте да укаже на аутономност ситуације исказане клаузом чији је део (МилосАвљЕВИЋ 2019: 53).

Бугарски лингвисти, углавном оријентисани на семантичка истраживања, дативну енклитику си терминолошки одређују као партикулу - модалну или прагматичку (Ретrova - SoKolov 2016; Савова 2017; Иванова - ПетровА 2017). Димка Савова (САВовА 2017) анализира семантику бугарских и пољских глагола и употребљеног „si/sobie елемента” у зависности од значења глагола. „Си елемент”, истиче Савова, може вршити различите функције - повратне

${ }^{4}$ Радивоје Младеновић истиче да се понегде срећу примери са дативском енклитиком $c u$ употребљеном у устаљеним изразима, типа: Блаі̄o си їа мужу за юу! (МлАденовић 2019: 439). 
заменице, формалне творбене партикуле - без утицаја на семантику лексеме, творбене партикуле која модофикује значење лексеме, прагматичке партикуле (која се не одражава на лексичко значење), граматичке партикуле (која мења граматичке и синтаксичке карактеристике глагола, везане углавном за његову валентност) (САвова 2017: 39). Необавезна употреба „елемента си” уз велику групу глагола у бугарском језику има функцију прагматичке партикуле, која указује да се радња врши за задовољством, спокојно, без бриге, да је природна и уобичајена (САвовА 2017: 50-51). Елена Иванова, Галина Петрова (Иванова - Петрова 2017) и Иван Соколов (Рetrova - SoKolov 2016) за исту функцију енклитике $c u$ користе термин „модална партикула”. Према овим ауторима, $c u$ као модална партикула је посебно честа у разговорном језику (ИвАновА - ПЕтровА 2017: 94). Модална партикула се може додати различитим типовима предиката, и на тај начин модификује, нијансира и спецификује значења радње изражене предикатом (Petrova - SoKolov 2016: 91; ИвАновА - ПЕтровА 2017: 94). Издвојена „нијансирана” значења на која утиче модална партикула су: 1) трајање, непроменљивост радње, 2) уобичајеност, регуларност, 3) постојање неке карактеристике, 4) задовољство, лична заинтересованост, 5) оповргавање изјаве или нечијег очекивања, 6) субјективна условљеност, 7) елиминација субјективности (у исказима генералног значења) (Petrova - Sokolov 2016: 92-93; Иванова - Петрова 2017: 94-95).

Енклитика $\mathrm{cu}$, тврде бугарски лингвисти, губи статус аутосемантичне јединице (ИвАновА - ПЕтровА 2017: 93). Сличног мишљења су и лингвисти коју исту појаву истражују у ромском језику, сматрајући датив рефлексивне заменице (у истој овој функцији) псеудо-конституентом са епистемичко-евалуативном интерпретацијом (MATRAS 2002: 101; LEGGIO 2011: 75).

3. ПРЕДМЕТ И ЦИљЕВИ ИСТРАЖИВАњА. ПредмеТ ОВОГ рада је УПОТреба енКЛИтичког облика датива рефлексивне заменице себе/се у незаменичкој функцији, за коју ће се даље у раду користити термин йарииикула си. Под незаменичком функцијом се у овом раду сматрају они случајеви употребе енклитичког облика рефлексивне заменице који у функционалном смислу не припадају заменичким функцијама - партикула $c u$ не замењује друге заменице, именице и/или именичке фразе (будући да се рефлексивна заменица сматра личном заменицом за свако лице, овде се не указује на придевске функције заменица), њена употреба се не ослања на анафору, која би у значењском смислу заменицу упућивала на антенцедент. У синтаксичком смислу, партикула $c u$ се не употребљава у заменичким конституенским функцијама, нпр. субјекат, логички субјекат, индиректни објекат и сл.

Будући да нема заменичку функцију, те да је изгубила и дативску функцију, примери који су предмет анализе указују да си постаје функционална реч, радњу изражену глаголом у предикату модификује, и/или нијансира и зато ће се у овом раду за си користити термин „партикула”.

Циљ овог рада је да се на основу примера ексцерпираних из тимочког поткорпуса (в. одељак 4) издвоје најфреквентнији обрасци употребе партикуле $c u$, који би могли да укажу на потенцијалне синтаксичке правилности (нпр. употреба партикуле $c u$ у непосредном контаксту са глаголом), али и 
варијације синтаксичких образаца њене употребе. За ове потребе употреба партикуле си биће истраживана по неколико критеријума:

1) лице и број глагола уз који је партикула $c u$ употребљена,

2) аниматност субјекта клаузе у којој је употребљена партикула $c u$,

3) рефлексивност глагола и конструкција у којима је употребљена пар-

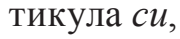

4) партикула си у клаузама са активном или пасивном дијатезом,

5) синтаксички обрасци употребе партикуле $c u$ у контактној позицији са пунозначним глаголом,

6) употреба и/или изостављање копуле (у копулативним предикатима) у контактној позицији са партикулом $\mathrm{cu,}$

7) употреба и/или изостављање рефлексивне заменице се (уз рефлексивне глаголе и конструкције) у контактној позицији са партикулом $\mathrm{cu}$,

8) партикула си и најфреквентнији глаголи.

4. УзорАк. Овај рад се заснива на теренској антрополошко-лингвистичкој грађи документованој у оквиру пројекта Чувари немайеријалне башйине

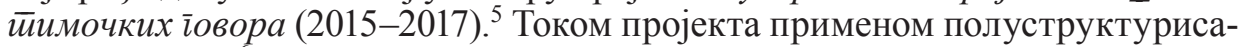
них интервјуа ${ }^{6}$ документован је обиман мултимедијални корпус грађе, који садржи 398 сати аудио-грађе, 192 сата видео-грађе и 4.460 фотографија.. Од планираних 96 пунктова, теренски су обрађена 92 насеља у општинама Књажевац, Зајечар и Сврљиг, ${ }^{8}$ која у дијалектолошком смислу припадају тимочким говорима призренско-тимочке говорне зоне (БЕлић 1905; СтАнојевић 1911; Динић 2008; Соболев 1994; Soвolev 1998; Ивић 2009). На основу документоване теренске грађе креиран је Spoken Torlak Dialect Corpus 1.0 (transcription) (VuKović 2020), у који је у првој, објављеној верзији укључена само грађа документована у насељима која припадају тимочким говорима и садржи око 500.000 речи. У састав корпуса је ушло 80 сати теренских раз-

${ }^{5}$ Пројекат је у два пројектна циклуса 2015. и 2016. године финансирало Министарство културе и информисања Републике Србије. Додатна теренска истраживања 2017. године спровођена су у пунктовима у којима нису били документовани узорци говора, или у случајевима недовољно прикупљене теренске грађе. Теренска истраживања током 2017. године финансирана су из сопствених средстава истраживача. Документовање теренских разговора са млађим саговорницима обављано је и 2018. године, у оквиру пројекта Језик, фолклор и миіраиије на Балкану, који је до 2020. финансирало Министарство образовања, науке и технолошког развоја Републике Србије. Неки од резултата теренског рада објављени су у зборнику радова Тимок.

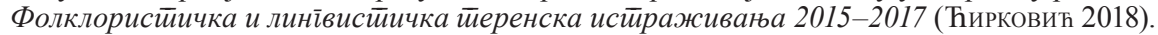

6 О методологији теренских истраживања као и списку тема за разговор в. Ћирковић 2018: 9-10; Конер и др. 2020.

7 У складу са правилима архивирања документовани теренски материјал се у целини чува у Дигиталном архиву Балканолошког института САНУ, на Филозофском факултету Универзитета у Нишу и у Народној библиотеци „Његош” у Књажевцу. Дигитални архив Балканолошког института САНУ је доступан корисницима интерне мреже Српске академије наука и уметности.

${ }^{8}$ Интерактивна мапа истражених пунктова доступна је на адреси: http://balksrv2012. sanu.ac.rs/webdict/timok/index (приступљено: 15. 3. 2021). Репрезентативни узорци говора, наратива из области традицијске културе и усмене историје монтирани су и постављени на Јутјуб канал „Теренска истраживања”, доступно на: https://www.youtube.com/channel/UC4EpCSAnEb2RIsIRY7pfNdQ (приступљено 18. 3. 2021). 
говора са 166 саговорника из 64 насеља која у дијалектолошком смислу припадају тимочким говорима (Vuković 2021). ${ }^{9}$

Аутоматском претрагом Spoken Torlak Dialect Corpus 1.0 добијено је 2.974 примера употребљене морфеме $c u{ }^{10}$ Делом машински, а делом ручно изостављени су примери у којима је си употребљено као друго лице једнине енклитичког облика помоћног глагола бий $u$, примери у којима $c u$ има заменичку функцију - функцију адноминалног посесора и индиректног објекта, као и примери непотпуног и не сасвим јасног значења. ${ }^{11}$ Коначан број ексцерпираних примера незаменичке употребе датива рефлексивне заменице $c u$ je 1.364, и ови примери су регистровани у наративима 83 саговорника, документованих у 58 насеља из тимочке говорне области.

\section{5. АНАЛИЗА}

5.1. ПАРТИКУЛА СИ - ЛИЦЕ И БРОЈ ГЛАГОЛА, АНИМАТНОСТ, РЕФЛЕКСИВНОСТ, дИјАТЕЗА. У овом одељку указује се на употребу партикуле $c u$ у односу на лице и број глагола, аниматност субјекта, рефлексивност глагола и активне и пасивне дијатезе у клаузи. У табелема 1-4 приказан је број примера у односу на поменуте категорије. Свака од поменутих категорија илустрована је примерима испод табеле. ${ }^{12}$

Табела 1. Број примера партикуле $с и$ у зависности од лица и броја глагола

\begin{tabular}{|c|c|c|}
\hline Лице & Једнина & Множина \\
\hline 1. & 259 & 224 \\
\hline 2. & 49 & 13 \\
\hline 3. & 600 & 219 \\
\hline
\end{tabular}

(1) Ја си водим коло. (1.л.јд) (Ргоште)

(2) А тој смо си звали котал. (1.л.мн) (Јаковац)

(3) Дадеш си на куче. (2.л.јд.) (Ошљане)

(4) Ви си поприћајте туј сас Наду. (2.л.мн) (Јаловик Извор)

(5) Она си се природно породила. (3.л.јд) (Црни Врх)

(6) И сад си постигну. (3.л.мн) (Понор)

Табела 2. Број примера партикуле $c u$ у зависности од аниматности субјекта

\begin{tabular}{|c|c|c|}
\hline Аниматност & Аниматни субјекат & Неаниматни субјекат \\
\hline Број примера & 1.152 & 212 \\
\hline
\end{tabular}

9 Тимочки поткорпус у оквиру Spoken Torlak Dialect Corpus 1.0 је један од резултата међународног пројекта (Dis-)entangling traditions on the Central Balkans: Performance and perception (TraCeBa). Корпус је доступан на линку: https:/www.clarin.si/noske/run.cgi/first_form?corpname=torlak;align=_(приступљено 15. 3. 2021). Финална верзија корпуса садржаће транскрибован анотиран теренски материјал и из насеља која припадају лужничким говорима. О принципима транскрибовања, анотирања теренске грађе као и о креирању електронског корпуса в. Vuković 2021 (приступљено 15. 3. 2021); MiLičević Petrović et al. (у процесу рецензирања).

10 Претрага је рађена октобра 2019. године.

${ }^{11}$ Примери непотпуног и не сасвим јасног значења последица су усмене нарације, коју карактеришу, између осталог, „погрешни почеци”, незавршене реченице и фразе, самоисправљање и сл., што доводи и до проблема са разумевањем (НоEKSTRA 2008: 142-143).

12 У свим примерима партикула $c u$ је маркирана тамним словима. 
(7) Ја си причам све најбоље с њим. (аниматан субјекат) (Мариновац)

(8) Па си ми пројде јутро. (неаниматан субјекат) (Јаковац)

Табела 3. Број примера партикуле $c u$ у зависности од рефлексивности глагола

\begin{tabular}{|l|c|c|}
\hline \multicolumn{1}{|c|}{ Рефлексивност } & Нерефлексивни глаголи & $\begin{array}{c}\text { Рефлексивни глаголи } \\
\text { и конструкције }^{13}\end{array}$ \\
\hline Број примера & 1.244 & 120 \\
\hline
\end{tabular}

(9) Ја сам си тој размишљала. (нерефлексивни глагол) (Понор)

(10) И шале си се као и саг. (рефлексивни глагол) (Ошљане)

Табела 4. Број примера партикуле $c u$ у зависности од дијатезе

\begin{tabular}{|l|l|l|}
\hline Дијатеза & Актив & Пасив \\
\hline Број примера & 1.310 & 54 \\
\hline
\end{tabular}

(11) А Бојана си отиде. (активна дијатеза) (Балинац)

(12) Само си доцкан посадено. (пасивна дијатеза) (Штипина)

Међу постојећим примерима партикула $c$ има највећу фреквенцу употребе уз глагол у 3. лицу једнине (600 примера, 43,99\%), док је најмање фреквентно 2. лице множине (13 примера, 0,95\%). Број примера са аниматним субјектом (исказаним и изостављеним) је 1.152 (84,46\%), док је у 212 примеpa $(15,54 \%)$ субјекат неаниматан. Такође, фреквентнији је модел клауза са нерефлексивним глаголима - 1.244 примера $(91,2 \%)$, док је употребљених рефлексивних (и реципрочних) глагола и рефлексивних конструкција 120 $(8,8 \%)$. Примери са глаголима у активној дијатези су фреквентнији и има их 1.310 (96,04\%), док је глагола у пасиву 54 (3,96\%).

5.2. СИНТАКСИЧКИ ОБРАСЦИ УПОТРЕБЕ ПАРТИКУЛЕ СИ У КОНТАКТНОЈ ПОЗИЦИЈИ СА ПУНОзНАЧним ГЛАГоЛом. Контактна позиција партикуле $c$ и и глагола пуног лексичког значења раздвојена је у обрасце који указују на позицију партикуле $c$ у односу на облике глагола - глагол у простом глаголском облику (Г), глагол у облику радног глаголског придева (РГП), глагол у одричном облику (НегГ), глагол у перфекту (ПГ + РГП). ${ }^{14}$ Облици глагола су раздвојени са циљем указивања на могуће варијације глагола уз које се партикула $c u$ налази у контактној позицији. Од 1.364 примера - у 927 примера (67,96\%) партикула cu се налази у контактној позицији са глаголом пуног лексичког значења. У Табели 5 наведен је пример за сваки образац контактне позиције партикуле cu и глагола и указује и на фреквенцу синтаксичких образаца позиције партикуле $c u$ и глагола - да ли се партикула налази испред или иза глагола. ${ }^{15}$ Примери са контактном позицијом партикуле си и копуле биће посебно анализирани у одељку 5.3.

${ }^{13}$ У анализи употребе партикуле $c u$ уз рефлексивне глаголе неће се посебно раздвајати рефлексивни и реципрочни глаголи. Под рефлексивним конструкцијама се сматрају конструкције са рефлексивним пасивом, које у својој структури садрже рефлексивну заменицу се.

${ }^{14} Г$ - глагол, РГП - радни глаголски придев, НегГ - одрични облик глагола, ПГ - помоћни глагол.

${ }^{15}$ У овом делу рада неће бити разматрана употреба и изостављање помоћног глагола у оквиру перфекта (уп. Vuкović et al. (у поступку рецензирања), између осталих). 
Табела 5. Број примера партикуле си у зависности од синтаксичког обрасца

\begin{tabular}{|c|c|c|c|c|c|c|c|}
\hline \multicolumn{4}{|l|}{$c u$ испред глагола } & \multicolumn{4}{l|}{$c u$ иза глагола } \\
\hline$c u+\Gamma$ & $c u+$ РГП & $c u+$ Нег & $c u+\Pi Г+$ РГП & $\Gamma+c u$ & РГП $+c u$ & РГП $+\Pi Г+c u$ & НегГ $+c u$ \\
\hline 449 & 144 & 7 & 7 & 232 & 66 & 18 & 4 \\
\hline
\end{tabular}

Контактна позиција партикуле $c u$ и глагола дефинисана је обрасцима $c u+\Gamma, c u+$ РГП, $c u+$ НегГ, $c u+$ ПГ + РГП - у којима је партикула $c u$ употребљена у позицији испред глагола у фукцији предиката (примери 13-16):

(13) Он си чека. $(c u+\Gamma)$ (Влахово)

(14) Ја сам си блажила. (си + РГП) (Мариновац)

(15) Код нас си не дојде толко. (си + НегГ) (Понор)

(16) Кој си је одил. (cu + ПГ + РГП) (Трговиште)

Позиција партикуле $c u$ испред глагола углавном је условљена присуством субјекта на првој позицији у клаузи (примери 13 и 14). У случајевима изостављеног субјекта позицију партикуле $c u$ испред глагола условљава употреба неког другог реченичног конституента на првој позицији (нпр. прилошке одредбе реализоване прилозима (17) или предлошко-падежним конструкцијама (пример 18)): $:^{16}$

(17) Зимус си додили. (Крента)

(18) У сало [село] си иде. (Бучје)

Будући да су примери настали у везаној говорној продукцији, у наративима се често говори о радњама које су у синтаксичком смислу паралелне, сукцесивне, напоредне. Прву позицију у независној напоредној клаузи (пример 19) и зависној клаузи (пример 20) може заузимати и везник ( $\bar{a} a$, односно $\kappa a g)$, али се уочава изостанак контактне позиције везника и субјекта:

(19) Истопимо си у топило, па си газимо по оној топило. (Ошљане)

(20) Кад си појдемо, остаимо туј код цркву. (Балинац)

Синтаксички образац контактне позиције глагола (Г) и партикуле $c u$ у којој се глагол налази испред партикуле $c u(\Gamma+c u$, РГП $+c u$, РГП + ПГ + $u$, НегГ $+c u)$ регистрован је у случајевима изостављеног субјекта или његове употребе на некој другој позицији у клаузи, и изостанка других реченичних конституената на првој позицији у клаузи (примери 21-24).

(21) Седим си овде. $(\Gamma+c u)$ (Лепена)

(22) Возил си он брата. (РГП $+c u)$ (Влахово)

(23) Навикли смо си такој. (РГП + ПГ + си) (Лепена)

(24) Не видим си и готово. (НегГ $+c u)$ (Дрвник)

Ипак, у корпусу је регистровано 11 примера у којима синтаксичком обрасцу $Г+c u$ или РГП $+c u$ претходи заменица (одн. употребљена је на првој позици у клаузи) и то у функцији субјекта (25) или објекта (26):

(25) Ја имам си доле собу. (Зам $+\Gamma+c u)$ (Балинац)

(26) Нешто прича си Бобан. (Зам $+\Gamma+c u)$ (Горња Соколовица)

${ }^{16}$ И други реченични конституенти се могу наћи на првој позицији у клаузи (нпр. објекат, везници и сл.). 
Позицију испред глагола у синтаксичком обрасцу $\Gamma+c u$ може заузимати и прилог (27) или везник (28):

(27) Малко дадем си доле на унуку. (Прил $+\Gamma+c u)$ (Горња Соколовица)

(28) Она е умрела, али идемо си и даље. (Вез $+\Gamma+c u)$ (Понор)

Иако је контактна позиција партикуле $c u$ и глагола у креираном корпусу примера најфреквентнији синтаксички образац (67,96\%), овај синтаксички образац може бити раздвојен другим реченичним конституентима. У 287 примера $(21,04 \%)$ партикула си није у контактној позицији са глаголом. ${ }^{17}$ Примери не указују на строго дефинисана правила распоређивања реченичних конституенета, поготову не оних који се могу наћи у позицијама између партикуле $c u$ и глагола. Субјекат не мора заузимати прву позицију у клаузи (пример 29).

(29) Па то сам си од детета ја научио. (Јања)

Између партикуле $c u$ и глагола могу се наћи различити реченични конституенти (примери који следе (30 и 31) илуструју употребу само неких реченичних конституената на позицији између партикуле $c u$ и глагола):

(30) Оне си тако иду заједно. (Лепена)

(31) Ми си тьк оно једемо. (Равно Бучје)

5.3. УПОТРЕБА И/ИЛИ ИЗОСТАВЉАҢЕ КОПУЛЕ (У КОПУЛАТИВНИМ ПРЕДИКАТИМА) У КОНТАКТНОЈ ПОЗИЦИЈИ СА ПАРТИКУЛОМ СИ. ПартикуЛа $\mathrm{cu}$ се Поред ГЛаГола са пуним лексичким значењем у функцији предиката употребљава и у клаузама са копулативним предикатима. Копулативни предикат има структуру копула + предикатив. Функцију копуле врши глагол бий и различитим глаголским облицима,${ }^{18}$ док функцију предикатива могу вршити именице, придеви, прилози, синтагме (именичке, придевске, прилошке) и предлошкопадежне конструкције са адвербијалним значењем.

Од 1.364 анализираних примера 150 примера (10,99\%) илуструје клаузе у којима је партикула $\mathrm{cu}$ употребљена уз копулативни предикат. Копулативни предикат у презенту употребљен је у 98 примера (65,33\%), док је копулативни предикат у перфекту употребљен у 49 примера (32,67\%). Копулативни предикат исказан неким другим глаголским обликом употребљен је у 3 примера (2\%) - два примера у футуру првом и један пример у потенцијалу.

У овим примерима варијације се односе на присуство/одсуство копуле у презенту, односно присуство/одсуство енклитичког облика презента помоћног глагола битu $u$, који улази у састав копуле у перфекту, и партикуле $c u .{ }^{19}$

Уочава се непостојање значајне варијације у присуству/одсуству енклитичког облика презента помоћног глагола бити у копули у перфекту - у 24

${ }^{17}$ Остали примери - њих 150 - издвојени су јер предствљају примере са копулативним предикатом, који ће се посебно анализирати.

${ }^{18}$ Копула у презенту реализована је енклитичким обликом глагола бий $и$, док је у перфекту копула реализована енклитичким обликом презента помоћног глагола битии и радним глаголским придевом глагола бит̄u.

${ }^{19}$ Будући да међу примерима има и копула у одричном облику (4 примера), одрични облик копуле подразумева њену обавезну употребу (нпр. Па несам си још била ни као девојчица. // Ама, несмо си ми више за овде сами, бре.). 
примера употребљена је енклитика помоћног глагола бийи (пример 32), док је у 25 примера енклитика изостављена у копули у перфекту (пример 33).

(32) Тьд смо си били овде. (копула у перфекту, помоћни глагол употребљен) (Дрвник)

(33) Он си там бил по Скопље. (копула у перфекту, помоћни глагол изостављен) (Штипина)

Категорије лица и броја су значајне за варирање присуства енклитичког облика презента помоћног глагола битии у копули у перфекту (Табела 6).

Табела 6. Број примера партикуле $c$ у копулативном предикату у зависности од лица и броја глагола и присуства/одсуства енклитике у перфекту

\begin{tabular}{|l|c|c|}
\hline \multicolumn{1}{|c|}{ Лице } & $\begin{array}{c}\text { Присуство енклитике } \\
\text { у копули у перфекту }\end{array}$ & $\begin{array}{c}\text { Одсуство енклитике } \\
\text { у копули у перфекту }\end{array}$ \\
\hline 1. лице једнине & 11 & 0 \\
\hline 1. лице множине & 7 & 0 \\
\hline 3. лице једнине & 5 & 21 \\
\hline 3. лице множине & 1 & 4 \\
\hline
\end{tabular}

Енклитички облик презента помоћног глагола бит̄и који формира копулу у перфекту обавезно се употребљава у 1 . лицу једнине и множине (није регистрован ниједан пример са изостављеном енклитиком у копули у перфекту). Чешће се изоставља у 3 . лицу једнине и множине - регистрован je 21 пример са изостављеном енклитиком у копули у 3 . лицу једнине, и 5 примера употребљене енклитике у копули у перфекту у истом лицу. У 3. лицу множине енклитика у копули у перфекту је изостављена у 4 примера, док је регистрован само један пример употребе енлитике у копули у перфекту (примери 34-37 илуструју употребу енклитике у копули у перфекту, док примери 38-39 илуструју изостављање енклитике у копули у перфекту).

(34) Ја сам си код башту била. (1.л.јд, копула у перфекту, помоћни глагол употребљен) (Врбица)

(35) Тьд смо си били овде. (1.л.мн, копула у перфекту, помоћни глагол употребљен) (Дрвник)

(36) А било си је лепо. (3.л.јд, копула у перфекту, помоћни глагол употребљен) (Репушница)

(37) Који су си били радници, они сви и после рата радели. (3.л.мн, копула у перфекту, помоћни глагол употребљен) (Ргоште)

(38) Он си там бил по Скопље. (3.л.јд, копула у перфекту, помоћни глагол изостављен) (Штипина)

(39) Моји си били онам сами. (1.л.мн, копула у перфекту, помоћни глагол изостављен) (Дебелица)

Варијација постоји у присуству/одсуству копуле у презенту (која је реализована енклитичким обликом глагола бий и у презенту) - у 64 примера копула је изостављена, док је у 34 примера копула употребљена. Употреба копуле у презенту варира и у категоријама лица и броја. Тенденција варијације употребе, одн. изостављања копуле у презенту у категоријама лица и броја слична је употреби/изостављању енклитике у копули у перфекту (Табела 7). 
Табела 7. Број примера партикуле $c$ у копулативном предикату у зависности од лица и броја глагола и присуства/одсуства енклитике у презенту

\begin{tabular}{|l|c|c|}
\hline \multicolumn{1}{|c|}{ Лице } & Присуство копуле у презенту & Одсуство копуле у презенту \\
\hline 1. лице једнине & 7 & 2 \\
\hline 1. лице множине & 5 & 2 \\
\hline 3. лице једнине & 18 & 48 \\
\hline 3. лице множине & 4 & 12 \\
\hline
\end{tabular}

Уз прво лице једнине и множине фреквенца употребе копуле је већа (укупно 12 примера) у односу на њено изостављање (укупно 4 примера). У трећем лицу једнине и множине фреквенца изостављања копуле је већа (укупно 60 примера) у односу на употребу копуле (22 примера). Примери који следе илуструју клаузе са копулом у презенту. У примерима (40-43) копула је употребљена, док је у примерима (43-47) копула изостављена.

(40) Сама сам си туј. (1.л.јд, копула у презенту, употребљена) (Жуковац)

(41) А ми смо си близа горе. (1.л.мн, копула у презенту, употребљена) (Трговиште)

(42) Она си је одовда. (3.л.јд, копула у презенту, употребљена) (Јања)

(43) Који су си ближњи, они иду. (3.л.мн, копула у презенту, употребљена) (Трновац)

(44) Ја си сама. (1.л.јд, копула у презенту, изостављена) (Трговиште)

(45) А ми си сиротиња. (1.л.мн, копула у презенту, изостављена) (Бучје)

(46) Он си и сад горе. (3.л.јд, копула у презенту, изостављена) (Бучје)

(47) Они си доле. (3.л.мн, копула у презенту, изостављена) (Жлне)

5.4. УПОТРЕБА И/ИЛИ ИЗОСТАВЉАњЕ РЕФЛЕКСИВНЕ ЗАМЕНИЦЕ СЕ (УЗ РЕФЛЕКСИВНЕ ГЛАГОЛЕ И КОНСТРУКЦИЈЕ) У КОНТАКТНОЈ ПОЗИЦИЈИ СА ПАРТИКУЛОМ СИ. ОД 1.364 примера, у 120 регистрована је употреба партикуле $c u$ уз рефлексивни (или реципрочни) глагол у предикату или уз рефлексивну конструкцију (рефлексивни пасив). У 72 примера (60\%) рефлексивна заменица се и партикула си су употребљене у истој клаузи, док је у 48 примера (40\%) рефлексивна заменица изостављена (Табела 8).

Табела 8. Број примера партикуле $c и$ у односу на присуство/одсуство рефлексивне заменице

\begin{tabular}{|l|c|c|}
\hline \multicolumn{1}{|c|}{ Рефлексивна заменица } & $\begin{array}{c}\text { Рефлексивна заменица } \\
\text { - употребљена }\end{array}$ & $\begin{array}{c}\text { Рефлексивна заменица } \\
- \text { изостављена }\end{array}$ \\
\hline Број примера & 72 & 48 \\
\hline
\end{tabular}

Пример (48) илуструје употребу рефлексивне заменице се (употребљена у оквиру рефлексивног глагола) и партикуле си у истој клаузи. Пример (49) илуструје изостављање рефлексивне заменице се у корист употребе партикуле $c u$. Примери (50) и (51) илуструју клаузе са рефлексивним конструкцијама (рефлексивни пасив), у којима је рефлексивна заменица употребљена (пример 50) или изостављена (пример 51).

(48) Дигнем си се ујутру. (Штипина)

(49) Ја си с њега врнем. (Доња Каменица)

(50) Други [колач] си се посе меси за Ђурђовдан. (Шести Габар)

(51) Таг си гледало тој. (Орешац) 
5.5. ПАРТИКУЛА СИ И НАЈФРЕКВЕНТНИЈИ ГЛАГОЛИ. За ПОтребе овоГ рада ИЗдвојени су најфреквентнији глаголи уз које се партикула си употребљава са циљем идентификовања ситуације маркиране партикулом $\mathrm{cu}$. Аутоматском претрагом 1.364 примера добијен је податак да се партикула $c u$ користи уз 329 глаголске леме. ${ }^{20}$ Најфреквентнија употреба партикуле $c u$ је уз глагол бийи у функцији копулативног предиката (који се под одређеним морфосинтаксичким условима изоставља, како је претходно показано) - у 150 примера $(10,99 \%)$. Следећи по фреквенцији употребе партикуле $c u$ уз глагол је глагол иматии (у посесивном и егзистенцијалном значењу) и има 109 потврда (7,99\%). Од глагола пуног лексичког значења најфреквентнији глаголи су: $u \hbar u, ~ o \bar{u} u \hbar u$, $g o \hbar u$, који припадају семантичкој класи глагола кретања, $\bar{u} р и ч а \bar{u} и$, глаголима говорења, знатии - глаголима мишљења, живе $\bar{u} u$ и сеgети $u$, који припадају семантичкој класи глагола мировања. ${ }^{21}$ Остали глаголи са мањом фреквенцом употребе уз партикулу си припадају у најширем могућем смислу класи

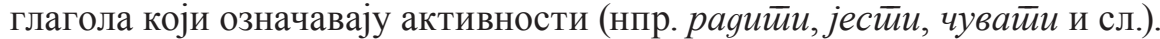

6. ДискусијА. За разлику од досадашњих дијалектолошких, семантичких и прагматичких истраживања употребе партикуле $c$ у говорима призренско-тимочке дијалекатске зоне (СтАнолевић 1911; БогдАНОВИћ 1979; 1987; Ћирић 1983; 1999; РАКић-Милолковић 1995; Вукадиновић 1996; Реметић 1996; ARSENIJEVIĆ 2013; МилосАвљЕвит 2019, између осталих) и сличних језичких феномена у балканским словенским језицима (PETROVA - SoKolov 2016; САвовA 2017; ИванОВА - ПЕтрова 2017, између осталих), истраживање употребе партикуле $c u$ у тимочким говорима заснива се на издвајању најфрекевентнијих синтаксичких образаца у којима се ова партикула јавља.

Резултати анализе показују да се партикула $c u$ користи најфреквентније уз нерефлексивне глаголе у активној дијатези са аниматним субјектом. Партикула си се јавља најчешће уз глагол у 3. лицу једнине. Тенденције употребе партикуле $c и$ уз одређено лице и број, као и друге испитиване карактеристике глагола, могу бити последица примењене теренске методологије и садржаја теренских разговора. У документовању тимочких говора примењивана је методологија полуструктурисаних интервјуа, али не и лингвистички упитници којима би се елицитирала одређена језичка појава или граматичка категорија, ${ }^{22}$ те самим тим, постоји могућност да би примена другачије лингвистичке методологије дала другачије резултате.

Квантитативна анализа примера указује на то да је најфреквентнији синтаксички образац употребе партикуле $c u$ њена директна контактна позиција са глаголом. Партикула си се понаша као „Вакернагелова клитика”, заузимајући другу позицију у клаузи. Релативно су ретки језици у којима је позиција клитика ограничена само на позицију после прве речи у клаузи

${ }^{20}$ У консултацијама са колегиницом Теодором Вуковић сугерисано ми је да треба рачунати са $10 \%$ грешке, будући да је реч о аутоматској анотацији, лематизацији и претрази.

${ }^{21}$ Семантичке класе глагола овде неће бити детаљније разматране, уп. VENDLER 1957; LONGACRE 1976; COOK 1979; JACKENDOFF 1983. О непостојању јединствене семантичке класификације глагола в. Тошовић 1998.

${ }^{22}$ Минимално је интервенисано усмеравањем разговора са циљем елицитације употребе неких глаголских облика, лексема и лексичких група (уп. Мирић 2018a: 98). 
(такозване $2 \mathrm{~W}$ клитике), у индоевропским језицима клитика се може јавити и после прве речи или после прве фразе у клаузи (2D клитике). „Вакернагелова клитика" је клитика која се може позиционирати управо после прве речи или после прве фразе у клаузи (SPENCER - Luís 2012: 41), што је случај и у српском језику (BoŠKOVIĆ 2000; Progovac 2000; DiesING - ZEC 2011, између осталих). ${ }^{23}$

Распоред глагола и партикуле $c u$ у примерима издвојеним из тимочког корпуса углавном зависи од распореда реченичних конституената у клаузи. Партикула $c u$ претходи глаголу у случајевима присуства неког од реченичних конституената на иницијалној позицији у клаузи - субјекта, правог објекта, везника, прилошких одредаба и сл. Глагол, пак, претходи партикули cu у случајевима када су наведени реченични конституенти распоређени на некој другој позицији у клаузи и када глагол заузима иницијалну позицију. Примери показују да се на иницијалној позицији не налази увек само једна реч, па самим тим партикула $c u$ не заузима другу позицију у клаузи. Ипак, скоро 21\% примера у којима партикула $c$ и глагол нису у контактној позицији, показује и да се контакт глагола и партикуле $c u$ може раздвојити реченичним конституентима, што може бити последица говорног језика, дигресивних одлика наратива, али се може тумачити и из перспективе информационе структуре реченице, фокусом и топикализацијом (уп. нпр. FÉRY- KRIFKA 2008; HALUPKA-REŠETAR 2009; 2011).

Партикула $c u$ утиче и на изостанак копуле у презенту и енклитичког облика помоћног глагола бити и у копули у перфекту. У 59,33\% примера копула у презенту и енклитички облик помоћног глагола бийu у копули у перфекту су изостављени, док су у $38,6 \%$ примера употребљени. Изостављање енклитичког облика глагола бит̄u - у функцији копуле у презенту или помоћног глагола бий и у перфекту у корист употребе партикуле $c u$ може се објаснити нагомилавањем језичких средстава, као што је то случај са другим морфосинтаксичким обележјима (РАкић-Милолковић 1995: 529-530; Мирић 2018a: 106-109; 2018б: 209). Уколико је копула исказана (било у перфекту, било у презенту), она се у свим случајевима налази у контактној позицији са партикулом $c u$, што синтаксички образац контактне позиције партикуле $c u$ и глагола чини још фреквентнијим.

Слична је ситуација и са изостављањем рефлексивне заменице се у клаузама у којима се партикула $c$ налази у контактној позицији са рефлексивним (и реципрочним) глаголима и рефлексивним конструкцијама. Изостављање рефлексивне заменице се у корист партикуле $c u$, слично као са копулом, може се тумачити нагомилавањем језичких средстава. Иако 40\% примера са изостављеном рефлексивном заменицом се не представља доминанатан синтаксички образац, они ипак указују на то да рефлексивна заменица може бити „слаба” клитика у односу на партикулу си.

Осим фреквентних синтаксичких образаца анализа примера је показала да се партикула $c$ најфреквеније употребљава уз пунозначне глаголе

${ }^{23}$ Важно је напоменути да се у цитираним студијама позиција клитика анализира у стандардном српском језику, а неретко се о позицији клитика говори у контексту српско-хрватског језичког континуума. 
који припадају семантичкој класи глагола кретања, говорења, мишљења и мировања. Ипак, треба имати у виду да издвајање примера са незаменичком употребом дативне енклитике $c u$ и креирање коначног корпуса за анализу почива на личној процени истраживача о употреби и функцији си. Наиме, аутоматском претрагом корпуса добијено је 2.974 примера, а ручном обрадом изостављени су примери у којима је си употребљено као 2. лице једнине глагола бити $u$, али и примери заменичке употребе $c u-$ у функцији индиректног објекта и адноминалног посесора, те као финални корпус примера за анализу добијено је 1.364 примера. Највећи изазов у процени употребе клитике $c u$ представљају глаголи који припадају семантичкој класи глагола давања, који су троаргументске структуре, односно, двотранзитивни глаголи. ${ }^{24}$ Глаголи давања као обавезан аргумент поред директног објекта имају и индиректни објекат у дативу. У функцији индиректног објекта се може наћи и енклитика $c u$, што отежава процену о њеној заменичкој и незаменичкој употреби. Поставља се питање да ли се уз глаголе давања може употребити партикула си или ту позицију заузима искључиво индиректни објекат истог морфолошког облика.

7. ЗАКљУЧНА РАЗМАТРАњА. Незаменичка употреба енклитичког облика датива рефлексивне заменице себе/се језичка је одлика типична за говоре призренско-тимочке дијалекатске зоне, којој припадају и тимочки говори. Реч је о употреби која у функционалном смислу не припада ниједној од регистрованих заменичких функција - индиректном објекту и адноминалном посесору; енклитички облик датива рефлексивне заменице губи заменичку и дативску функцију, постаје функционална реч и добија функцију партикуле.

Истраживање изложено у овом раду настало је на обимном и релевантном корпусу, емпиријском и квантитативном анализом. Анализа теренске грађе документоване у теренским истраживањима насеља која у дијалектолошком смислу припадају тимочким говорима указала је на најфреквентније обрасце употребе партикуле $c u$ и варијације синтаксичких образаца, који осветљавају однос партикуле $c u$ и глагола у зависности од његових категорија (лице, број, рефлексивност, дијатеза), варијацију распореда реченичних конституената у клаузи у којој је употребљена партикула си. Издвојени синтаксички обрасци указују и на употребу и изостављање копуле у копулативном предикату и рефлексивне заменице у рефлексивним глаголима и конструкцијама у зависности од употребљене партикуле $c u$, а издвојени су и најфреквентнији глаголи уз које се ова партикула користи.

Добијени резултати су у великој мери условљени примењеном методологијом теренских истраживања, на основу којих је креиран и корпус. Примена других лингвистичких метода могла би да даิ другачије резултате. Синтаксичке варијабле у употреби партикуле $c u$ би се могле испитивати применом експерименталне методологије и/или синтаксичких упитника у којима би изворни говорници дијалекта процењивали прихватљивост другачијег распореда енклитика, глагола и партикуле $c u$, (не)заменљивост $c u$ другим заменицама, именицама и именичким фразама уз глаголе уз које стоји

${ }^{24}$ О двотранзитивним глаголима (енг. ditransitive verbs) в. ILIĆ 2016: 109-114. 
неправи објекат. На овај начин би се могло установити да ли енклитика $c u$ уз глаголе давања осим у заменичкој функцији може бити употребљена и у незаменичкој, одн. као партикула. Осим тога, у даљим истраживањима би се могла детаљније испитати и контактна позиција партикуле $c u$ и рефлексивне заменице се.

\section{ЦИТИРАНА ЛИТЕРАТУРА}

БЕлић, Александар. Дијалекти источне и јужне Србије. Срйски gијалекӣолощки зборник I (1905): VII-CXII, 1-674.

БогдАновић, Недељко. Говори Бучума и Белог Потока. Срйски gијалекӣолощки зборник XXV (1979): XII-XV, 1-178.

БогдАновић, Недељко. Говор Алексиначког Поморавља. Срйски gијалекӣолощки зборник XXXIII (1987): 7-302.

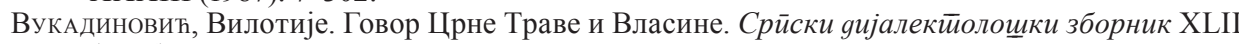
(1996): 1-317.

Динић, Јакша. Тимочки gијалекайски речник. Београд: Институт за српски језик САНУ, 2008.

ИвановА, Елена Юрьвна, Галина Михайлова ПетровА. Болгарские возвратые клитики СЕ и СИ: Омонимия, полисемия, синтаксис. Воироосы языкознания 1 (2017): 74-104.

Ивић, Павле. Срйски gијалекӣи и ғихова класификаиија (прир. Слободан Реметић). Нови Сад - Сремски Карловци: Издавачка књижарница Зорана Стојановића, 2009.

Јуришић, Марина. Говор Горње Пчиње. Београд: Институт за српски језик САНУ, 2009.

КонЕР, Д. В., А. Л. МАКАРОВА, С. ЧиРКович. Опыт составления программы для полевого исследования дивергенции и конвергенции традиций Центральных Балкан. Вестник Томского Государственного Университета. Филология 65 (2020): 109-126.

МАрковић, Јордана. Говор Заплања. Срйски яијалекйолощки зборник XLVII (2000): 7-307.

МилосАвљевић, Стефан. Семантика и прагматика евалуативног рефлексивног датива у говору јабланичког краја (у светлу сродних феномена у другим језицима/говорима). Милош Ковачевић, Јелена Петковић (ур.). Савремена ироучавања језика и књижевносӣи X/1. Крагујевац: Филолошко-уметнички факултет, 2019, 45-56.

Мирић, Мирјана. Граматикализација футура првог и изостављање субјунктивног маркера $g a$ у лужничком говору јужног типа зоне I (Буковик). Зборник Майице срйске за филолойју и линиввистикку LXI/2 (2018a): 89-125.

Мирић, Мирјана. Употреба/изостављање субјунктивног маркера ga у конструкцији футура првог у тимочким говорима. Светлана Ћирковић (ур). Тимок. Фолклорисииччка и линїви-

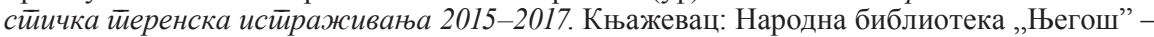
Београд: Удружење фолклориста Србије, 2018б, 201-218.

МлАденовић, Радивоје. Говор шарпланинске жупе Гора. Срйски яијалектиолощки зборник XLVIII (2001): 1-606.

Младеновић, Радивоје. Замениие у їоворима јуі̄озайаgно̄ gела Косова и Мейохије. Београд: Институт за српски језик САНУ, 2010.

Младеновић, Радивоје. Говор јужнокосовскої села Гайње. Београд: Институт за српски језик САНУ, 2013.

МлАденовић, Радивоје. Говор северношарпланинске жупе Сиринић. Срйски gијалекӣолощки зборник LXVI/ 1 (2019): 1-1047.

ПАвловић, Миливој. Говор Јањева. Нови Сад: Матица српска, 1970.

Пецо, Асим, Бранислав МилАновић. Ресавски говор. Срйски дијалекӣолощки зборник XVII (1968): 241-366.

Пипер, Предраг, Иван КлАлн. Нормайивна ірамайика срӣской језика. Нови Сад: Матица српска, 2013.

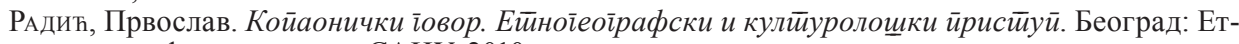
нографски институт САНУ, 2010.

РАкић-Милолковић, Софија. Основе морфолошког система говора Доње Мутнице (код Параћина). Срйски gијалекӣолощки зборник XXXVI (1990): 75-118. 
РАкић-Милолковић, Софија. Синтаксички упитник за говоре косовско-ресавске и призренскотимочке дијалекатске зоне. Срйски яијалект̄олощки зборник XLI (1995): 521-570.

Реметић, Слободан. Српски призренски говор. Срииски gијалекӣолощки зборник XLII (1996): 319-614.

САвовА, Димка. Глаголи с елемента си/sobie в българския и в полски език. Zeszyty Cyrylo-Metodiańskie 6 (2017): 38-56.

Соболев, Андрей Н. Говор села Вратарница в восточной Сербии. München: Verlag Otto Sagner, 1994.

СоБолев, Андрей Н. Иерархия участников ситуации и «скрытый посесор». От значения к форме, от формы к значению: Сб. Статей к 80-летнию члена-корреспондента РАН А. В. Бонgарко. Санкт Петербург: ИЛИ РАН, 2012, 523-529.

Станојевић, Маринко. Северно-тимочки дијалекат. Срйски яијалекӣолощки зборник II (1911): $360-465$.

Тошовић, Бранко. Универзална семантичка класификација глагола. Научни састианак у Вукове gане 27/2 (1998): 113-124.

Ћирић, Љубисав. Говор Лужнице. Срйски дијалекӣолощки зборник XXIX (1983): 7-119.

Ћирић, Љубисав. Говори Понишавља. Срйски дијалекиеиолощки зборник XLVI (1999): 7-262.

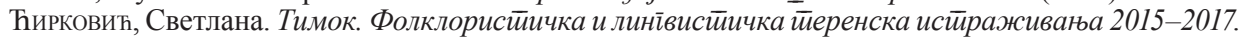
Књажевац: Народна библиотека „Његош” - Београд: Удружење фолклориста Србије, 2018.

ArSEnIJEvić, Boban. Evaluative Reflexions: Evaluative Dative Reflexive in Southeast Serbo-Croatian. B. Fernandez, R. Etxepare (eds.). Variations in Datives: A Microcomparative Perspective, Oxford: Oxford University Press, 2013, 1-21.

BošKović, Željko. Second Position Cliticisation. Syntax and/or Phonology?. Frits Beukema, Marcel Den Dikken (eds). Clitic Phenomena in European Languages. Amsterdam - Philadelphia: John Benjamins Publishing Company, 2000, 71-119.

Соoк, Walter A. Case Grammar: Development of the Matrix Model (1970-1978). Washington D.C.: Georgetown University Press, 1979.

Diesing, Molly, Draga Zec. Interface Effects: Serbian Clitics. Syntax and Semantics 37 (2011): 1-30.

FÉRY, Caroline, Manfred KRIFKA. Information Structure: Notional Distinctions, Ways of Expression. Piet van Sterkenburg (ed.). Unity and Diversity of Languages. Amsterdam: John Benjamins Publishing Company, 2008, 123-135.

HALUPKA-REŠETAR, Sabina. Red reči u službi izražavanja informacionog fokusa u srpskom jeziku. Зборник Майице срӣске за филолоїију и линївисииику LII/2 (2009): 169-186.

HaluPKA-ReŠEtaR, Sabina. Rečenični fokus u engleskom i srpskom jeziku. Novi Sad: Filozofski fakultet Univerziteta u Novom Sadu, 2011.

HoEkstra, Eric. The Predicate-Argument Relation and the Structure of Discourse in Spoken Frisian. Studia Linguistica 62/1 (2008): 142-153.

ILIĆ, Nina. Verb Production at Different Stages of Language Acquisition. Sabina Halupka-Rešetar, Silvia Martinez-Ferreiro (eds.). Studies in Language and Mind. Novi Sad: Faculty of Philosophy, 2016, 107-160.

JACKendoff, Ray. Semantics and Cognition. MIT Press, 1983.

Kemmer, Suzzane. The Middle Voice. Amsterdam - Philadelphia: John Benjamins Publishing Company, 1993.

Leggio, Daniele Viktor. The Dialect of the Mitrovica Roma. Romani Studies 5, Vol. 21, No.1 (2011): $57-114$.

Longacre, Robert. An Anatomy of Speech Notions. Lisse: Peter de Ridder Press, 1976.

Matras, Yaron. Romani. A Linguistic Introduction. Cambridge: Cambridge University Press, 2002.

Miličević Petrović, Maja, Teodora Vuković, Mirjana Mirić, Daria Konior, Anastasia Escher. Towards a Sociolinguistic Corpus of Torlak: Challenges for Data Processing. Zeitschrift für Slavische Philologie (у процесу рецензирања).

Petrova, Galina, Ivan Sokolov. Bulgarian-English Parallels in the Translations of Structures with the Modal Particle $c и(s i)$. Гоgищник на Универсииетеи ,Проф. Д-Р Асен Злайаров“ XLV/2 (2016): 90-94.

Progovac, Ljiljana. Where do Clitics Cluster?. Frits Beukema, Marcel Den Dikken (eds). Clitic Phenomena in European Languages. Amsterdam - Philadelphia: John Benjamins Publishing Company, 2000, 249-258. 
Sobolev, Andrej N. Sprachatlas Ostserbiens und Westbulgariens I-III. Marburg - Lahn: Biblion Verlag, 1998.

Spencer, Andrew, Ana R. Luís. Clitics. An Introduction. Cambridge: Cambridge University Press, 2012.

UhLIK, Rade. Govori jugoslovenskih Cigana u okviru Balkanskog jezičkog saveza. Godišnjak, knjiga 10, Centar za balkanološka ispitivanja, knjiga 8 (1973): 53-108. Sarajevo, Akademija nauka Bosne i Hercegovine.

Vendler, Zeno. Verbs and Times. Philosophical Review 66/2 (1957): 143-160.

Vuкоvić, Teodora. Spoken Torlak dialect corpus 1.0 (transcription). Slovenian language resource repository CLARIN.SI, http://hdl.handle.net/11356/1281, 2020.

Vuković, Teodora. Representing Variation in a Spoken Corpus of an Endangered Dialect: The Case of Torlak. Lang Resources \& Evaluation (2021). <https://doi.org/10.1007>

Vuković, Teodora, Anastasia Escher, Barbara Sonnenhauser. Degrees of Non-standardness. Feature-based Analysis of Variation in a Torlak Dialect Corpus. Empirical Approaches to Linguistic Variation: The Balkans and Beyond. 11-12 March 2021, Slavisches Seminar, University of Zurich, 2021 (презентација).

Vuković, Teodora, Mirjana Mirić, Anastasia Escher, Svetlana Ćirković, Maja MiličEvić Petrović, Andrey N. Sobolev, Barbara Sonnenhauser. Under the Magnifying Glass. Dimension of Variation in the Contemporary Timok Variety. Zeitschrift für Slavische Philologie (у процесу рецензирања).

Svetlana Ćirković

\section{NON-PRONOMINAL USE OF THE DATIVE ENCLITIC SI \\ IN THE TIMOK VERNACULARS: SYNTACTIC PATTERNS}

\section{Su m m a ry}

This paper explores the use of the dative case of the reflexive pronoun sebe/se in a non-pronominal function in the Timok vernaculars. The study made use of the corpus entitled Spoken Torlak Dialect Corpus 1.0, from which 1,364 examples were obtained through automatic search and manual selection. Based on these examples the most frequent patterns of use of the particle si were identified, which indicate the syntactic regularities and variations of the syntactic patterns of use of the particle $s i$. The use of the particle si is explored in relation to the following variables: 1) the person and number of the verb with which the particle si is used, 2) the animacy of the subject of the clause in which the particle $s i$ is used, 3) the reflexivity of the verb and construction in which the particle $s i$ is used, 4) the particle $s i$ in clauses with active and passive diathesis, 5) the syntactic patterns of use of the particle $s i$ in a contact position with the lexical verb, 6) the use and/or omission of the copula (in copulative predicates) in a contact position with the particle $s i, 7$ ) the use and/or omission of the reflexive pronoun se (with reflexive verbs and constructions) in a contact position with the particle $s i, 8)$ the use of the particle $s i$ with the most frequent verbs.

The results of the analysis indicate that in the Timok vernaculars the particle $s i$ is most frequently used with non-reflexive verbs in active diathesis with an animate subject. The quantitative analysis of the examples indicates that the most frequent syntactic pattern of use of the particle $s i$ is in a direct contact position with the verb. The order of the verb and the particle si mostly depends on the order of the constituents in the clause. The particle si precedes the verb in cases where one of the constituents such as the subject, direct object, conjunction, adverbials, etc. is present at the initial position in the clause. The verb precedes the particle si in cases where the given constituents are arranged in a different position in the clause and the verb holds the initial position.

The particle $s i$ also leads to the omission of the copula in the present tense and the enclitic form of the auxiliary verb biti ('to be') in the copula in the perfect tense, as well as the omission of the reflexive pronoun se in clauses in which the particle $s i$ is in contact with the reflexive and (reciprocal) verbs and reflexive constructions. The explanation for the omission of the enclitic form of the verb biti (in the function of the copula in the present tense or the auxiliary verb biti in the perfect tense) in favor of the use of the particle $s i$, as well as the omission of the reflexive pronoun se in favor of the particle $s i$, can be the accumulation of numerous linguistic elements. 
In addition to revealing the most frequent syntactic patterns, the analysis of the examples has shown that the particle $s i$ is most frequently used with lexical verbs that belong to the semantic classes of verbs of motion, speaking, thinking, and stillness.

Балканолошки институт САНУ

(Примљено: 20. марта 2021;

Кнез Михаилова 35/IV, 11000 Београд, Србија

прихваћено: 12. маја 2021)

svetlana.cirkovic@bi.sanu.ac.rs 